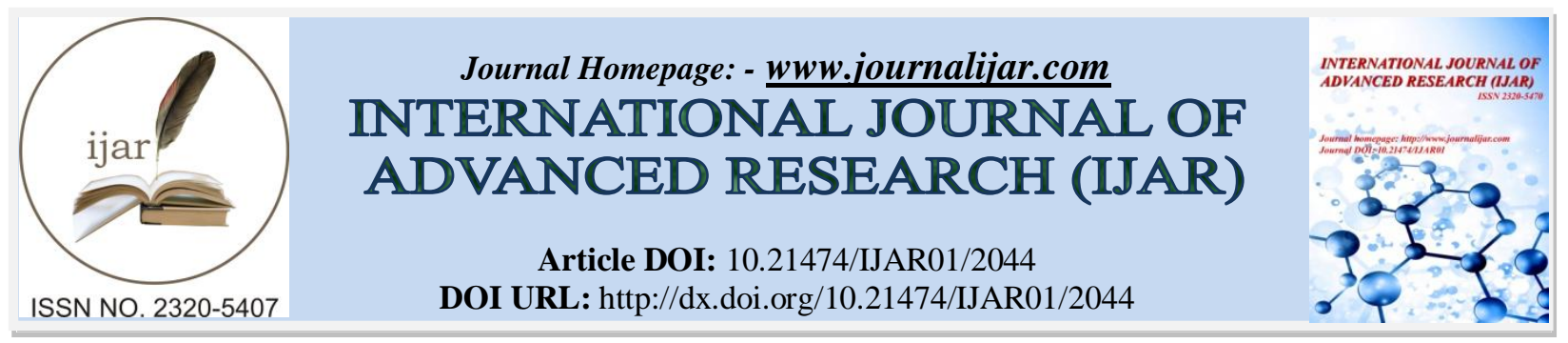

RESEARCH ARTICLE

\title{
INVESTIGATIONS ON SOME CHEMICAL INDICES IN BLOOD OF DOGS AFTER EXPERIMENTAL ACUTE INTOXICATION WITH THE CARBAMATE INSECTICIDE CARBOFURAN.
}

Rumen Binev*, Ivan Valchev, Anton Russenov and Yordan Nikolov.
Faculty of Veterinary Medicine; Trakia University, Student's Campus, 6000 Stara Zagora, Bulgaria.

\section{Manuscript Info}

Manuscript History

Received: 29 September 2016

Final Accepted: 15 October 2016

Published: October 2016

Key words:-

blood chemical indices, intoxication, carbamate insecticide, carbofuran, dogs

\section{Abstract}

Experiments for monitoring of changes in blood levels of some chemical indices were carried out in dogs after acute intoxication with the carbamate insecticide carbofuran (Carbosan $35 \mathrm{CT}$ ).

The studies involved one control and 6 experimental groups of dogs (totaln=42), treated once orally with increasing doses of the preparation via oesophageal probe : $0.525 \mathrm{mg} / \mathrm{kg}$ (experimental group I), $1.05 \mathrm{mg} / \mathrm{kg}$ (experimental group II), $2.1 \mathrm{mg} / \mathrm{kg}$ (experimental group III), $3.5 \mathrm{mg} / \mathrm{kg}$ (experimental group IV), $5.25 \mathrm{mg} / \mathrm{kg}$ (experimental group V) and $10.5 \mathrm{mg} / \mathrm{kg}\left(\mathrm{LD}_{50}\right)$, (experimental group $\mathrm{VI}$ ), corresponding to $1 / 20,1 / 10,1 / 5,1 / 3,1 / 2$ and $\mathrm{LD}_{50}$, oral doses for albino rats.

Blood samples were obtained from v. antebrachicephalicaorv. Jugularis in the course of 3 consecutive days prior to the treatment (hours -48, -24 and 0) and on post treatment hours 1, 3, 5, 7, 24 and 48 from all groups for analysis of calcium $(\mathrm{Ca})$, inorganic phosphorus $(\mathrm{P})$, magnesium $(\mathrm{Mg})$, total (TBil) and direct bilirubin (DBil), urea (BUN), creatinine (Creat), triglycerides (TG), cholesterole (Chole), plasma total protein (TP), albumin (Alb), blood glucose (Glu), potassium $(\mathrm{K})$,chlorides $(\mathrm{Cl})$ and sodium $(\mathrm{Na})$.

It was established that the tested carbamate insecticide caused increased the levels of TP, Glu, BUN, TG and Chole, and decrease $\mathrm{Mg}$ and $\mathrm{K}$. There were no considerable changes in the levels of Creat, Alb, Tbil, Dbil, $\mathrm{Ca}, \mathrm{P}, \mathrm{Cl}$ and $\mathrm{Na}(\mathrm{p}>0.05)$.

Copy Right, IJAR, 2016,. All rights reserved.

\section{Introduction:-}

The intoxication with organo carbamate compounds (OCC) is due to their ability to bind the serine group of acetyl cholinesterase through carbamylation of serine hydroxyl group. Unlike the mechanism of action of organophosphate compounds, the carbamylation of $\mathrm{AChE}$ is reversible and the obtained carbamate complex is hydrolysed again. Most commonly, the reactivation takes about 48 hours (Binev et al., 2014; Gupta, 2015).

OCC are mainly used as insecticides and less frequently, as nematocides and acaricides (Vlcek and Pohanka, 2012). They bind the serine group of acetylcholinesterase through carbamylation of serine hydroxyl group. Unlike the mechanism of action of organophosphate compounds, the carbamylation of AChE is reversible and the obtained carbamate complex is hydrolysed again. Most commonly, the reactivation takes about 48 hours. The wide use of 
carbamate pesticides is due mainly to their high toxicity (Berny et al., 2010). These features are the reason for reported large-scale intoxications of wild animals - mammals and birds(Novotný et al., 2011;Ogada, 2014; RuizSuárez et al., 2015). The reported accidents most frequently result from use of these compounds as baits (Kervegant et al., 2013) with raticides for restriction of populations of harmful rodents (voles) (Guitart, et al., 2010a). Although this mode of utilisation is the most efficient known as far, the use of OCC with this purpose is gradually limited because of the high ecotoxicity risk(Guitart, et al., 2010b). Newer data reported in the literature(Arnot et al., 2011; de Siqueira et al., 2015;Ruiz-Suárez et al., 2015), confirmed by our clinical cases show that very often, OCC (usually carbofuran) are used for deliberate poisoning of stray dogs and cats for restriction of their populations.

Carbofuran(2,3-dihydro-2,2-dimethyl-7-benzofuranylmethylcarbamate) is the most commonly used OCC due to its high biological activity against pests. At the same time, it is highly toxic $\left(\mathrm{LD}_{50}<50 \mathrm{mg} / \mathrm{kgm}\right)$, has no specific odour, possesses a high biological activity against crop pests and preserves its toxicity in the environment for a long time (Gupta, 1994). These features, as well its broad use, create prerequisites for its occurrence in water, soil, foods of plant origin and explains the numerous cases of intoxications in animals and humans(Rizos et al., 2004; Berny et al., 2010; Guitart, et al., 2010a,b;Vandenbroucke et al., 2010;Novotný et al., 2011; Aleksicetal., 2011).

Some of blood changes occurring after experimental intoxications with carbofuran and other organo carbamates have been investigated in fish (Begum and Vijayaraghavan, 2001; Soufu, et al., 2007; Thoker, 2015) and rats (Kaur and Sandhir, 2006; Rai and Sharma, 2007; Rai et al., 2009; Kaur et al., 2012; Gbadegesinet al., 2014; Jaiswal et al., 2015), but no data are available in dogs.

\section{Material and methods:-}

Experimental animals. The experiments were carried out on $42 \mathrm{dogs}$, at the same age and weight. Thirty days prior to the study they were kept in individual cages under the same conditions in compliance to hygienic microclimatic and feeding norms. The animals were fed canine food for adults (Lyubimets) and had free access to water.

Testedsubstance. The experimental intoxication was done with the commercial preparation Carbosan35 ST (Agro Science, USA), containing $350 \mathrm{mg}$ carbofuran(2, 3-dihydro-2, 2-dimethyl-7-benzofuranyl methyl carbamate) in 1 $\mathrm{mL}$, with oral $\mathrm{LD}_{50}$ for albino rats $=10.5 \mathrm{mg} / \mathrm{kg}$. The preparation was applied once orally via an oesophageal probe, two hours before feeding (at $6.00 \mathrm{AM}$ ).

Experimental design. The dogs were divided into 7 groups with equal number from both genders: one control and six experimental (6 dogs in each), treated on hour 0 with increasing single doses as followed: experimental group I: $0.525 \mathrm{mg} / \mathrm{kg}\left(1 / 20 \mathrm{LD}_{50}\right.$, for albino rats); experimental group II(1/10 LD $\mathrm{L}_{50}$, for albino rats): $1.05 \mathrm{mg} / \mathrm{kg}$; experimental group III: $2.1 \mathrm{mg} / \mathrm{kg}\left(1 / 5 \mathrm{LD}_{50}\right)$; experimental group IV: $3.5 \mathrm{mg} / \mathrm{kg}\left(1 / 3 \mathrm{LD}_{50}\right)$; experimental group V: 5.25 $\mathrm{mg} / \mathrm{kg}\left(1 / 2 \mathrm{LD}_{50}\right)$, and experimental group VI: $10.5 \mathrm{mg} / \mathrm{kg}\left(\mathrm{LD}_{50}\right)$.

Blood samples were obtained from v. antebrachicephalicaorv. Jugularis in the course of 3 consecutive days prior to the treatment (hours $-48,-24$ and 0 ) and on post treatment hours 1, 3, 5, 7, 24 and 48 from all groups for analysis of calcium $(\mathrm{Ca}, \mathrm{mmol} / \mathrm{l})$, inorganic phosphorus $(\mathrm{P}, \mathrm{mmol} / \mathrm{l})$, magnesium $(\mathrm{Mg}, \mathrm{mmol} / \mathrm{l})$, total $(\mathrm{TBil})$ and direct bilirubin (DBil, $\mu \mathrm{mol} / \mathrm{l}$ ), urea $(\mathrm{BUN}, \mathrm{mmol} / \mathrm{l})$, creatinine (Creat, $\mu \mathrm{mol} / \mathrm{l})$, triglycerides $(\mathrm{TG}, \mathrm{mmol} / \mathrm{l})$, cholesterole (Chole, $\mathrm{mmol} / \mathrm{l}$ ), plasmatotalprotein (TP, mmol/l), albumin (Alb, mmol/l),bloodglucose (Glu, mmol/l), potassium (K, $\mathrm{mmol} / \mathrm{l}$ ), chlorides ( $\mathrm{Cl}, \mathrm{mmol} / \mathrm{l})$ and sodium ( $\mathrm{Na}, \mathrm{mmol} / \mathrm{l})$ using commercial kits CybaCorning (BayerDiagnosticsLtd, Germany) and automated biochemical analyser OlympusAU 600 (Japan).

All results were processed with statistical software (Statistica 6.0 for Windows, StatSoftInc. USA, 1993). The significance of differences between treated groups and untreated controls were evaluated by ANOVA. The level of statistical significance was $\mathrm{p}<0.05$.

\section{Results:-}

After the treatment with carbofuran, blood total protein levels increased (Fig. 1).In the second group, statistically significant changes were observed only on post treatment hour $3-72.4 \pm 2.9 \mathrm{~g} / \mathrm{l}(\mathrm{p}<0.05)$ vs control levels $62.3 \pm 2.6 \mathrm{~g} / \mathrm{l}$. In the third group, this parameter was increased between post treatment hours 3 and 7 with peak on hour 3 ( $72.3 \pm 3.1 \mathrm{~g} / \mathrm{l} ; \mathrm{p}<0.05 \mathrm{vs}$ controls). Blood total protein concentrations in dogs from the fourth and fifth group were considerably higher from the $1^{\text {st }}$ to the $7^{\text {th }}$ hours. The maximum values of the studied parameter were observed 
by the $1^{\text {st }}$ hour $(77.7 \pm 3.4 \mathrm{~g} / \mathrm{lat} \mathrm{p}<0.01$ and $91.6 \pm 4.1 \mathrm{~g} / \mathrm{lat} \mathrm{p}<0.001$, respectively), compared to the control group $(59.3 \pm 2.8 \mathrm{~g} / \mathrm{l})$. The levels of the parameter in groups III, IV and $\mathrm{V}$ were restored by the $24^{\text {th }}$ hour.

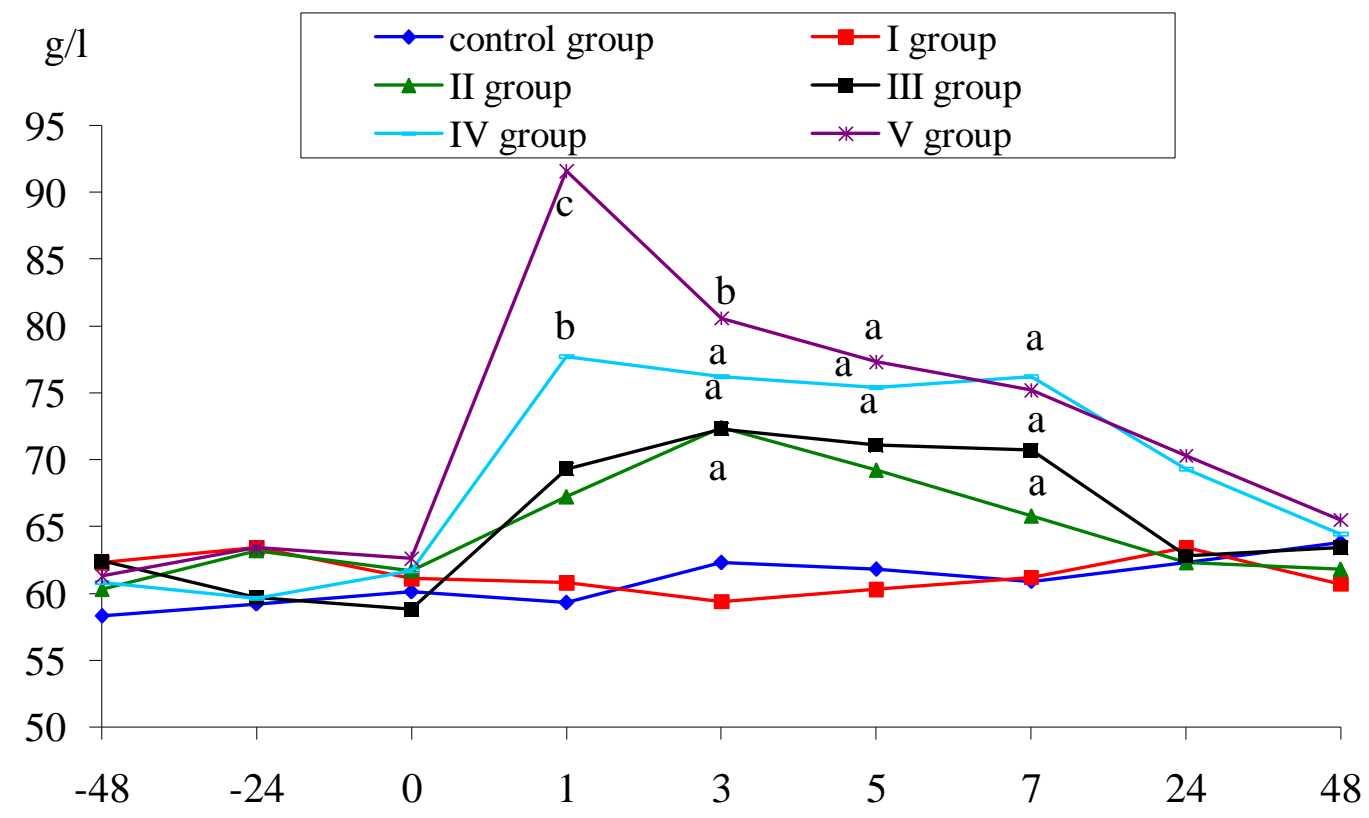

Fig. 1:- Changes in total protein levels in blood of dogs - untreated (control) and treated with carbofuranat doses $0.525 \mathrm{mg} / \mathrm{kg}\left(1 / 20 \mathrm{LD}_{50}\right.$ ), (group I), $1.05 \mathrm{mg} / \mathrm{kg}\left(1 / 10 \mathrm{LD}_{50}\right.$ ), (group II), $2.1 \mathrm{mg} / \mathrm{kg}$ (1/5 LD $\mathrm{LD}_{50}$ ), (group III), 3.5 $\mathrm{mg} / \mathrm{kg}\left(1 / 3 \mathrm{LD}_{50}\right)\left(\right.$ group IV) and $5.025 \mathrm{mg} / \mathrm{kg}\left(1 / 2 \mathrm{LD}_{50}\right)$, (group V): ${ }^{\mathrm{a}} \mathrm{p}<0.05 ;{ }^{\mathrm{b}} \mathrm{p}<0.01 ;{ }^{\mathrm{c}} \mathrm{p}<0.001$.

After the treatment with the toxic substance carbofuran, all treated groups of dogs exhibited increased blood glucose concentrations (Fig. 2) on hour 1. The respective measured levels in groups I, II, III, IV and V were 6.43 \pm 0.43 $\mathrm{mmol} / \mathrm{l}(\mathrm{p}<0.05), 6.88 \pm 0.42 \mathrm{mmol} / \mathrm{l}(\mathrm{p}<0.05), 7.86 \pm 0.52 \mathrm{mmol} / \mathrm{l} \quad(\mathrm{p}<0.01), 8.27 \pm 0.66 \mathrm{mmol} / \mathrm{l} \quad(\mathrm{p}<0.01)$ and $17.58 \pm 1.32 \mathrm{mmol} / \mathrm{l}(\mathrm{p}<0.001)$, as compared to control dogs- $5.03 \pm 0.33 \mathrm{mmol} / \mathrm{l}$. The changes observed on hour 1 were the maximum ones. Control values were attained again by post treatment hours 3 (group I), 5 (group II), 24 (group III) and 48 (group IV). In the fifth treatment group, blood glucose remained statistically significantly elevated until the end of the experiment.

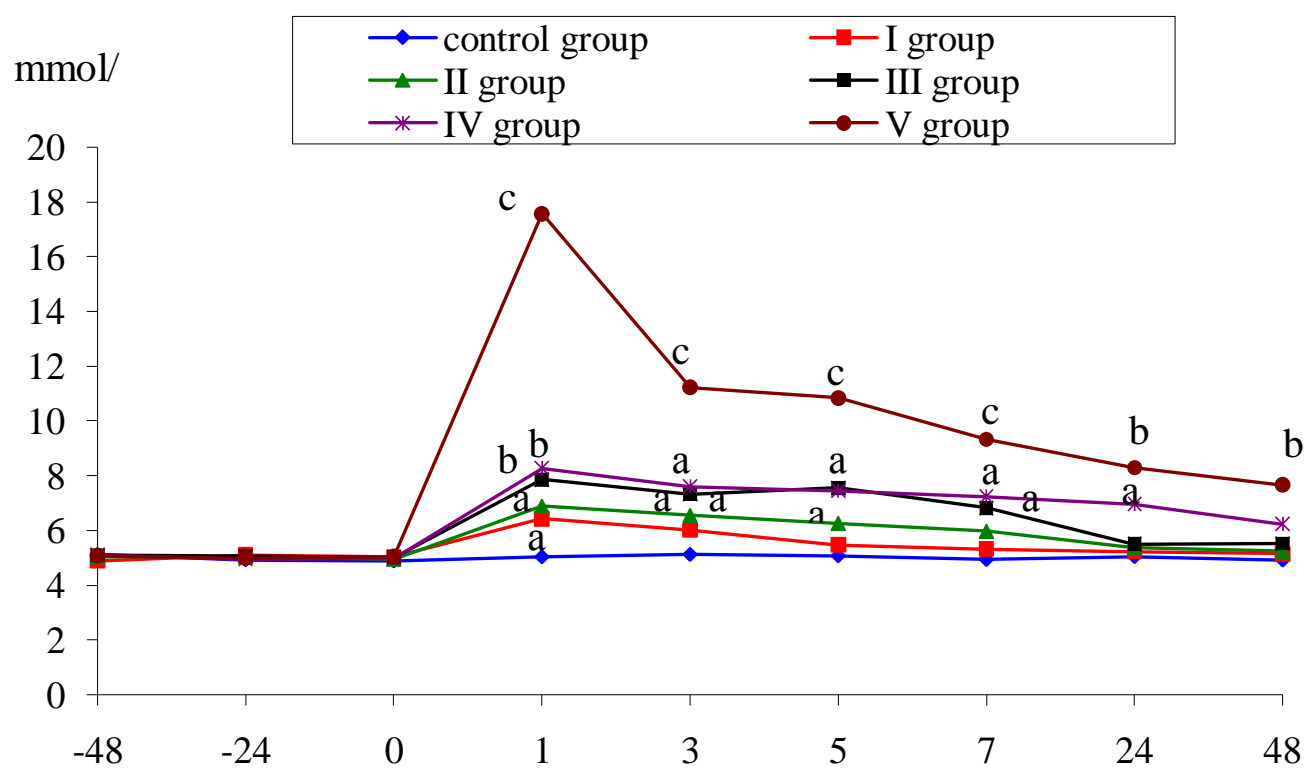


Fig. 2:- Changes in glucose levels in blood of dogs - untreated (control) and treated with carbofuranat doses 0.525 $\mathrm{mg} / \mathrm{kg}\left(1 / 20 \mathrm{LD}_{50}\right)$, (group I), $1.05 \mathrm{mg} / \mathrm{kg}\left(1 / 10 \mathrm{LD}_{50}\right)$, (group II), $2.1 \mathrm{mg} / \mathrm{kg}\left(1 / 5 \mathrm{LD}_{50}\right)$, (group III), $3.5 \mathrm{mg} / \mathrm{kg}(1 / 3$ $\mathrm{LD}_{50}$ ) (group IV) and $5.025 \mathrm{mg} / \mathrm{kg}\left(1 / 2 \mathrm{LD}_{50}\right)$, (group V): ${ }^{\mathrm{a}} \mathrm{p}<0.05 ;{ }^{\mathrm{b}} \mathrm{p}<0.01 ;{ }^{\mathrm{c}} \mathrm{p}<0.001$.

Blood urea (Fig. 3) was increased 1 hour after the treatment in groups III, IV and V-7.45 $\pm 0.66 \mathrm{mmol} / \mathrm{l}(\mathrm{p}<0.05)$, $9.18 \pm 0.76 \mathrm{mmol} / \mathrm{l}(\mathrm{p}<0.01)$ and $10.43 \pm 0.81 \mathrm{mmol} / \mathrm{l}(\mathrm{p}<0.01)$, vs controls $-5.14 \pm 0.45 \mathrm{mmol} / \mathrm{l}$. These were also the maximum registered values in these groups. In groups I and II no statistically significant changes in blood urea have occurred. Blood urea was restored by the $3^{\text {rd }}$ hour in group III, by the $7^{\text {th }}$ hour in group IV and by the $48^{\text {th }}$ hour in group V.

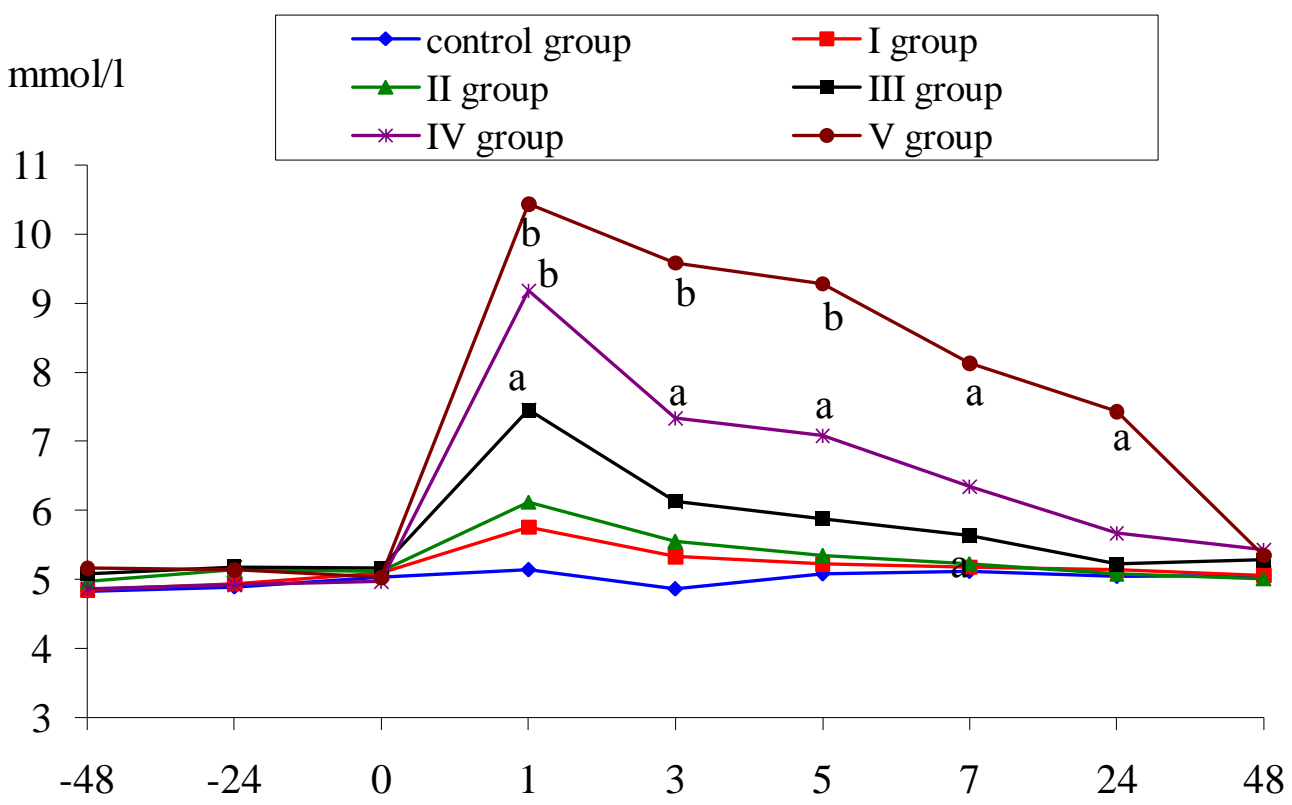

Fig. 3:- Changes in urea levels in blood of dogs - untreated (control) and treated with carbofuranat doses 0.525 $\mathrm{mg} / \mathrm{kg}\left(1 / 20 \mathrm{LD}_{50}\right.$ ), (group I), $1.05 \mathrm{mg} / \mathrm{kg}\left(1 / 10 \mathrm{LD}_{50}\right)$, (group II), $2.1 \mathrm{mg} / \mathrm{kg}\left(1 / 5 \mathrm{LD}_{50}\right)$, (group III), $3.5 \mathrm{mg} / \mathrm{kg}(1 / 3$ $\mathrm{LD}_{50}$ ) (group IV) and $5.025 \mathrm{mg} / \mathrm{kg}\left(1 / 2 \mathrm{LD}_{50}\right.$ ), (group V): ${ }^{\mathrm{a}} \mathrm{p}<0.05 ;{ }^{\mathrm{b}} \mathrm{p}<0.01 ;{ }^{\mathrm{c}} \mathrm{p}<0.001$.

Blood total cholesterol concentrations (Fig. 4) increased one hour after the treatment in groups II, III, IV and V and attained $5.38 \pm 0.41 \mathrm{mmol} / \mathrm{l}(\mathrm{p}<0.05), 6.63 \pm 0.48 \mathrm{mmol} / \mathrm{l}(\mathrm{p}<0.01), 7.16 \pm 0.51 \mathrm{mmol} / \mathrm{l}(\mathrm{p}<0.01)$ and $8.78 \pm 0.58 \mathrm{mmol} / \mathrm{l}$ $(\mathrm{p}<0.001)$ respectively vs controls $-4.04 \pm 0.32 \mathrm{mmol} / \mathrm{l}$. For all groups, reported values were the maximum ones. In group I, changes were irrelevant while in group II they were significant only by the $1^{\text {st }}$ hour. Blood cholesterol concentrations returned to normal values by the $5^{\text {th }}$ hour (group III), $24^{\text {th }}$ hour (group IV) and the $48^{\text {th }}$ hour (group V).

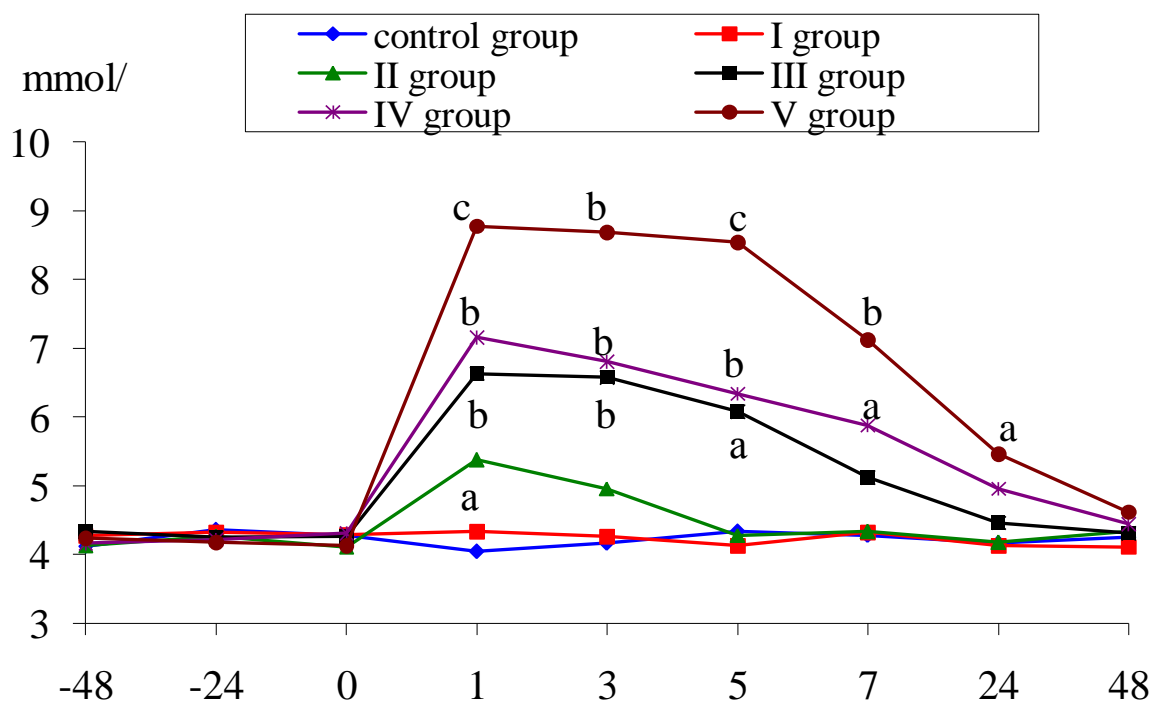


Fig. 4:- Changes in cholesterol levels in blood of dogs - untreated (control) and treated with carbofuranat doses $0.525 \mathrm{mg} / \mathrm{kg}\left(1 / 20 \mathrm{LD}_{50}\right.$ ), (group I), $1.05 \mathrm{mg} / \mathrm{kg}\left(1 / 10 \mathrm{LD}_{50}\right.$ ), (group II), $2.1 \mathrm{mg} / \mathrm{kg}\left(1 / 5 \mathrm{LD} \mathrm{D}_{50}\right.$ ), (group III), $3.5 \mathrm{mg} / \mathrm{kg}$ $\left(1 / 3 \mathrm{LD}_{50}\right)$ (group IV) and $5.025 \mathrm{mg} / \mathrm{kg}\left(1 / 2 \mathrm{LD}_{50}\right)$, (group V): ${ }^{\mathrm{a}} \mathrm{p}<0.05 ;{ }^{\mathrm{b}} \mathrm{p}<0.01 ;{ }^{\mathrm{c}} \mathrm{p}<0.001$.

The pattern of blood triglycerides changes (Fig. 5) was similar to that of cholesterol. This blood parameter increased statistically significantly one hour after carbofuran treatment in group II: $0.76 \pm 0.04 \mathrm{mmol} / \mathrm{l}(\mathrm{p}<0.05)$, group III: $0.86 \pm 0.05 \mathrm{mmol} / \mathrm{l}(\mathrm{p}<0.05)$, group IV: $0.86 \pm 0.04 \mathrm{mmol} / \mathrm{l}(\mathrm{p}<0.01)$ and group V: $1.02 \pm 0.06 \mathrm{mmol} / \mathrm{l}$ $(\mathrm{p}<0.001)$ vs controls $-0.62 \pm 0.03 \mathrm{mmol} / \mathrm{l}$. Reported triglyceride levels were the highest during the experimental period in respective groups. Normal values in groups II, III, IV and V were regained by hours 3, 5, 7, and 24 respectively. In the first group, blood triglycerides did not change substantially.

Blood magnesium levels(Fig. 6) decreased statistically significantly by the $5^{\text {th }}$ post treatment hour ingroups II, III, IV and $\mathrm{V}$ with respective values of $0.72 \pm 0.06 \mathrm{mmol} / \mathrm{l}(\mathrm{p}<0.05), 0.71 \pm 0.06 \mathrm{mmol} / \mathrm{l}(\mathrm{p}<0.05), 0.68 \pm 0.05 \mathrm{mmol} / \mathrm{l}(\mathrm{p}<0.05)$ and $0.52 \pm 0.04 \mathrm{mmol} / \mathrm{l}(\mathrm{p}<0.05)$, vs control measurements- $0.96 \pm 0.08 \mathrm{mmol} / \mathrm{l}$. After post treatment hour 7 , magnesium concentrations were already normalized.

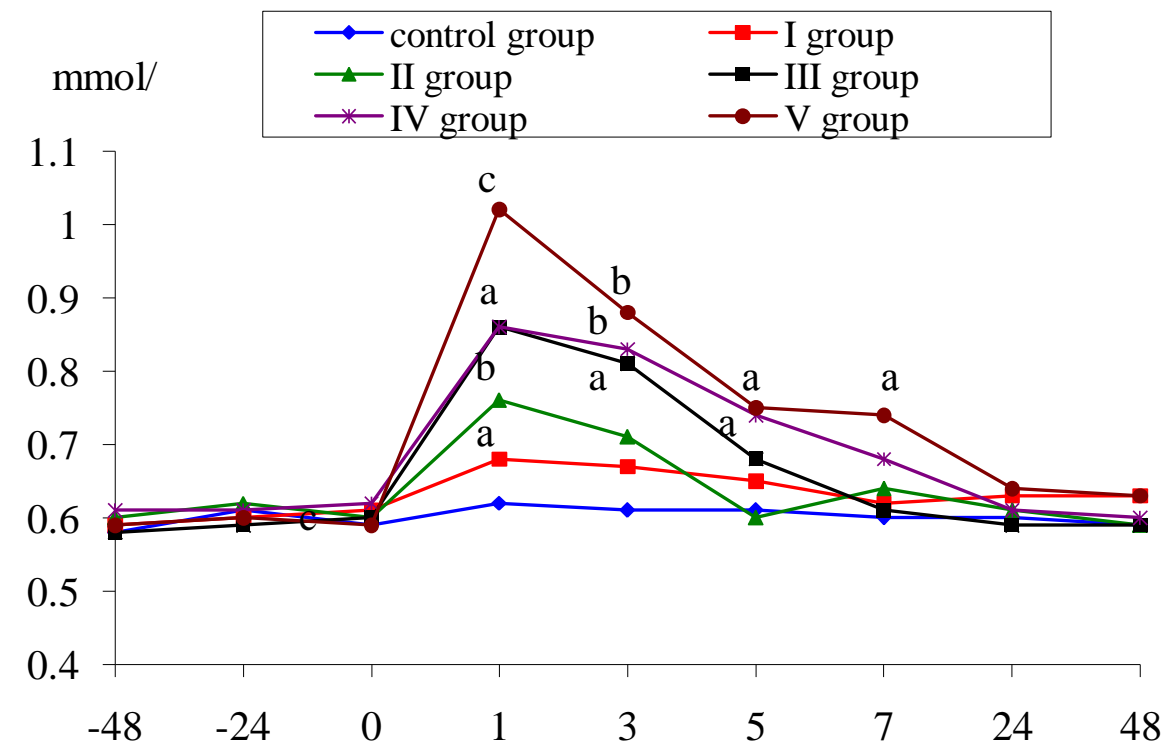

Fig. 5:- Changes in triglycerides levels in blood of dogs - untreated (control)and treated with carbofuranat doses $0.525 \mathrm{mg} / \mathrm{kg}\left(1 / 20 \mathrm{LD}_{50}\right.$ ), (group I), $1.05 \mathrm{mg} / \mathrm{kg}\left(1 / 10 \mathrm{LD}_{50}\right.$ ), (group II), $2.1 \mathrm{mg} / \mathrm{kg}\left(1 / 5 \mathrm{LD}_{50}\right.$ ), (group III), 3.5 $\mathrm{mg} / \mathrm{kg}\left(1 / 3 \mathrm{LD}_{50}\right)\left(\right.$ group IV) and $5.025 \mathrm{mg} / \mathrm{kg}\left(1 / 2 \mathrm{LD}_{50}\right)$, (group V): ${ }^{\mathrm{a}} \mathrm{p}<0.05 ;{ }^{\mathrm{b}} \mathrm{p}<0.01 ;{ }^{\mathrm{c}} \mathrm{p}<0.001$.

Blood potassium time course (Fig. 7) was characterized with a reduction in all experimental groups one hour after the treatment: $4.13 \pm 0.31 \mathrm{mmol} / \mathrm{l}(\mathrm{p}<0.05)$ in groupI, $4.13 \pm 0.30 \mathrm{mmol} / \mathrm{l}(\mathrm{p}<0.05)$ in groupII, $4.06 \pm 0.29 \mathrm{mmol} / \mathrm{l}$ $(\mathrm{p}<0.05)$ in group III, $3.81 \pm 0.29 \mathrm{mmol} / \mathrm{l}(\mathrm{p}<0.01)$ in group IV and $3.78 \pm 0.28 \mathrm{mmol} / \mathrm{l}(\mathrm{p}<0.01)$ in group V where as respective average values in controlswere $5.42 \pm 0.32 \mathrm{mmol} / \mathrm{l}$.In groups I, II and III, the registered values were the lowest registered. In groups IV and V, lowest blood $\mathrm{K}$ 
concentrations were attained by the $5^{\text {th }}$ hour: $3.70 \pm 0.29 \mathrm{mmol} / \mathrm{l}(\mathrm{p}<0.01)$ and $3.70 \pm 0.28 \mathrm{mmol} / \mathrm{l}(\mathrm{p}<0.01)$ respectively, vs controls $5.89 \pm 0.34 \mathrm{mmol} / \mathrm{l}$. The baseline concentrations of the first group were restored by the $5^{\text {th }}$ hour, in group II, III and IV - by the $24^{\text {th }}$ hours while in group V - by the $48^{\text {th }} \mathrm{h}$.

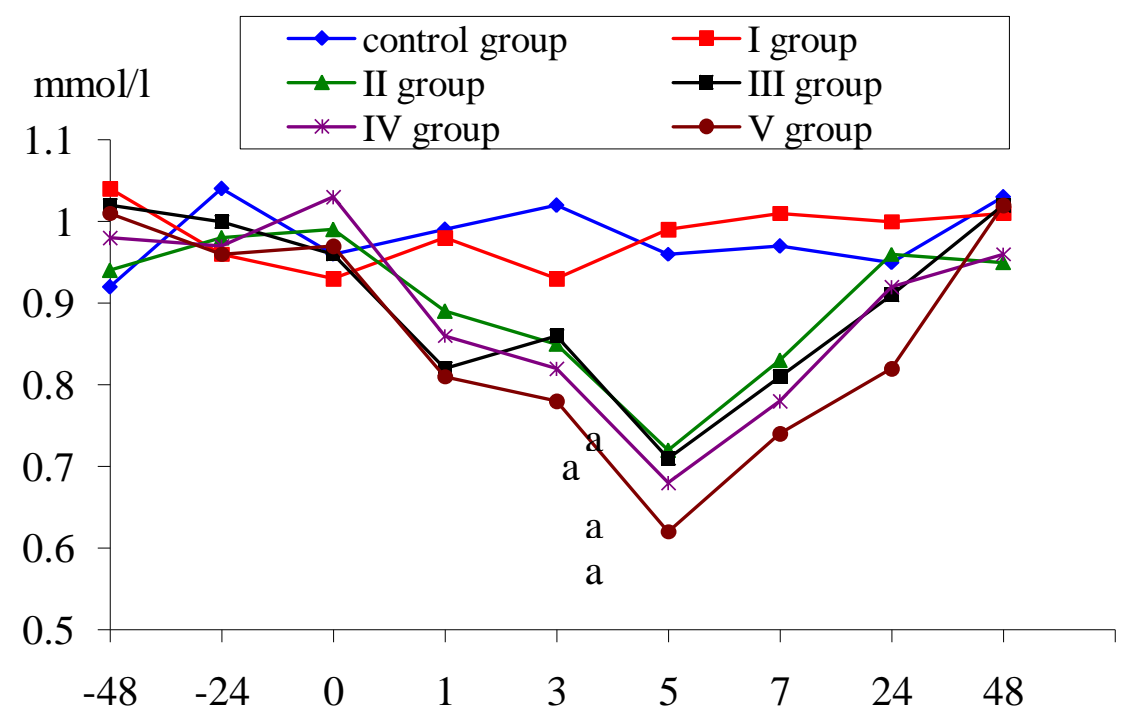

Fig. 6:- Changes in magnesium levels in blood of dogs - untreated (control) and treated with carbofuranat doses0.525 mg/kg (1/20 LD ${ }_{50}$ ), (group I), $1.05 \mathrm{mg} / \mathrm{kg}\left(1 / 10 \mathrm{LD}_{50}\right.$ ), (group II), $2.1 \mathrm{mg} / \mathrm{kg}\left(1 / 5 \mathrm{LD}_{50}\right.$ ), (group III), 3.5 $\mathrm{mg} / \mathrm{kg}\left(1 / 3 \mathrm{LD}_{50}\right)$ (group IV) and $5.025 \mathrm{mg} / \mathrm{kg}\left(1 / 2 \mathrm{LD}_{50}\right)$, (group V): ${ }^{\mathrm{a}} \mathrm{p}<0.05 ;{ }^{\mathrm{b}} \mathrm{p}<0.01 ;{ }^{\mathrm{c}} \mathrm{p}<0.001$.

There were no considerable changes in the levels of creatinine $(62.7 \pm 8.6 \mu \mathrm{mol} / \mathrm{l})$, albumin $(30.26 \pm 2.8 \mathrm{mmol} / \mathrm{l})$, total $(2.63 \pm 0.18 \mu \mathrm{mol} / \mathrm{l})$ and direct bilirubin $(0.58 \pm 0.07 \mu \mathrm{mol} / \mathrm{l})$, chlorides $(118.7 \pm 3.6 \mathrm{mmol} / \mathrm{l})$, calcium $(2.69 \pm 0.28$ $\mathrm{mmol} / \mathrm{l})$, inorganic phosphorus $(1.64 \pm 0.16 \mathrm{mmol} / \mathrm{l})$ and sodium $(152.1 \pm 2.8 \mathrm{mmol} / \mathrm{l})(\mathrm{p}>0.05)$.

Dogs treated at $10.5 \mathrm{mg} / \mathrm{kg}\left(\mathrm{LD}_{50}\right)$, (experimental group VI) showed signs of intoxication after the $5^{\text {th }}$ minute and died within 30 to 45 min after the treatment. 


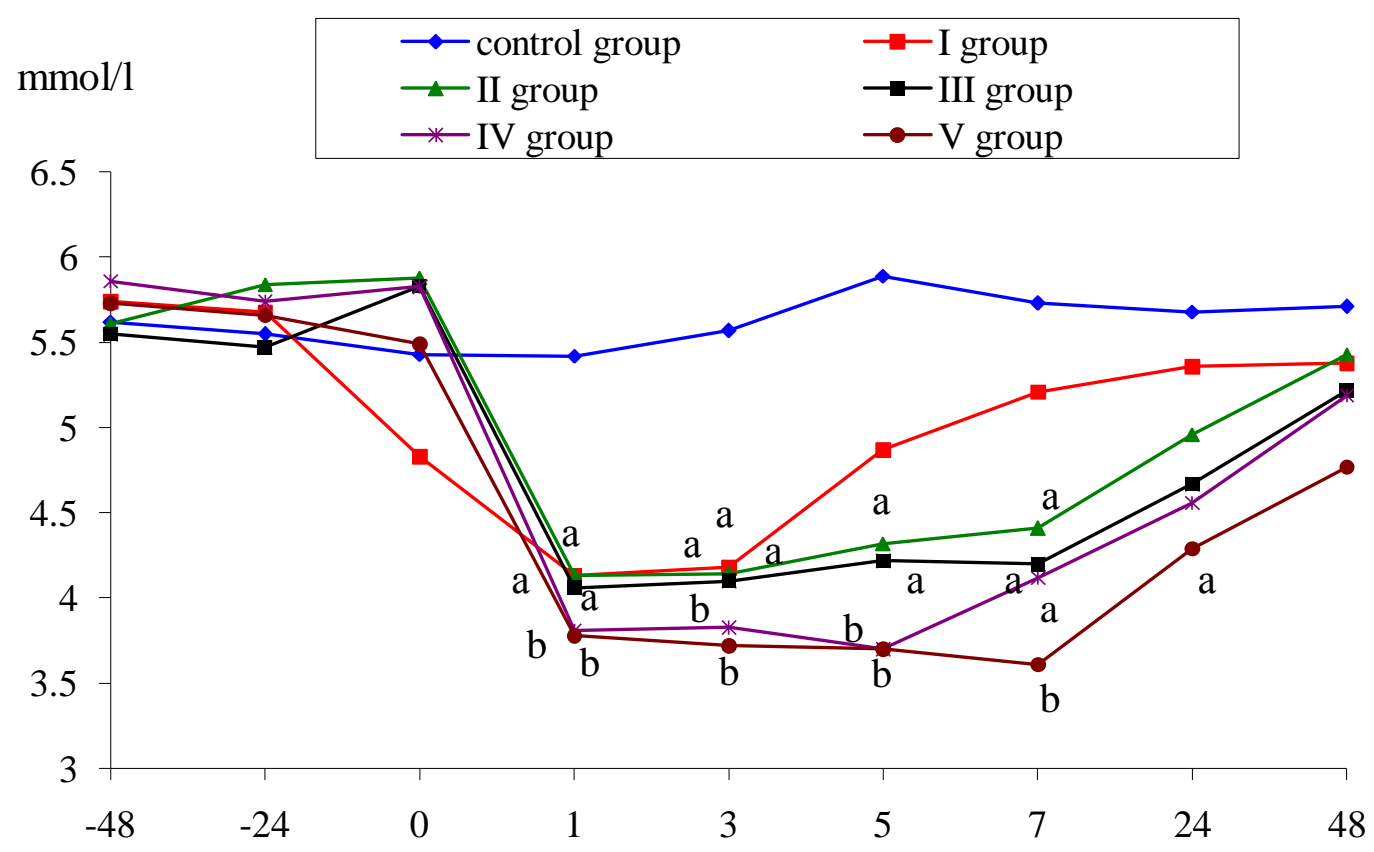

Fig. 7:- Changes in potassium levels in blood of dogs - untreated (control) and treated with carbofuranat doses0.525 $\mathrm{mg} / \mathrm{kg}\left(1 / 20 \mathrm{LD}_{50}\right)$, (group I), $1.05 \mathrm{mg} / \mathrm{kg}\left(1 / 10 \mathrm{LD}_{50}\right.$ ), (group II), $2.1 \mathrm{mg} / \mathrm{kg}\left(1 / 5 \mathrm{LD}_{50}\right)$, (group III), $3.5 \mathrm{mg} / \mathrm{kg}(1 / 3$ $\mathrm{LD}_{50}$ ) (group IV) and $5.025 \mathrm{mg} / \mathrm{kg}\left(1 / 2 \mathrm{LD}_{50}\right)$, (group V): ${ }^{\mathrm{a}} \mathrm{p}<0.05 ;{ }^{\mathrm{b}} \mathrm{p}<0.01 ;{ }^{\mathrm{c}} \mathrm{p}<0.001$.

\section{Discussion:-}

The studies conducted to evaluate the changes in some blood biochemical parameters in dogs treated with increased doses $\left(1 / 20 \mathrm{LD}_{50}, 1 / 10 \mathrm{LD}_{50}, 1 / 5 \mathrm{LD}_{50}, 1 / 3 \mathrm{LD}_{50}\right.$ and $\left.1 / 2 \mathrm{LD}_{50}\right)$ of the carbamate pesticide carbofuran demonstrated the substantial toxic effects of the preparation on the animal organism.

The analysis of results showed increased total protein, although blood albumin varied close to initially measured values. Changes were observed between post treatment hours 1 to 7 , with peak values between the $1^{\text {st }}$ the $3^{\text {rd }}$ hours in animals receiving high doses of carbofuran $\left(1 / 3 \mathrm{LD}_{50}\right.$ and $\left.1 / 2 \mathrm{LD}_{50}\right)$. In experimental groups treated at lower doses $\left(1 / 10 \mathrm{LD}_{50}\right.$ and $\left.1 / 5 \mathrm{LD}_{50}\right)$, the changes were less obvious and observed between the $3^{\text {rd }}$ and the $7^{\text {th }}$ hour. Our data are in line with those reported by Rizosetal. (2004) in humans and Zhelev (2004) in poultry and swine but not with results of Zaahkouketal. (2000) in rats, reporting hypo protein aemia and hypo albumin aemia consequently to inhibited protein synthesis caused by carbamate insecticides. Our results confirm the opinion of Rizosetal. (2004), that acute pancreatitis observed by them and other researchers (Gbadegesin et al., 2014;Jaiswal et al., 2015) as well, and the inflammation especially inbile ducts and liver parenchyma (cholangiohepatitis) were the cause for increased blood serum proteins in intoxicated animals. In the view of Zhelev (2004) a possible cause for higher blood total protein and albumin could be destructive effects of carbofuran on hepatocytes, as well as dehydration observed after poisoning with anticholinesterase pesticides.

The observed hyper glycaemia was probably associated to hepato toxic effect for ganocarbamates, which caused structural and functional disturbances of liver (Agrawal and Sharma, 2010; Jaiswal et al., 2015) and resultant enhanced conversion of glycogen to blood glucose (Kaur and Sandhir, 2006). A cause for higher blood glucose concentrations could be also increased blood epinephrine level secondary to neurotoxic effect of carbamate insecticides (Rizos et al., 2004), which cause poisoning with severe excitation signs (seizures, convulsions, tremor, clonic spasms of muscles etc.) (Binev et al., 2014). According to some authors (Zhelev, 2004), the rapidly occurring hyper glycaemia after carbofuran treatment is due to hyper acetylcholinaemia resulting from cholinesterase inhibition, and thus, the toxic compound affects indirectly the carbohydrate metabolism.It is acknowledged that acetylcholine regulates adrenal ganglion and that its accumulation in synapses causes enhanced release of catecholamines (epinephrine and dopamine) from adrenal glands. The accumulation of acetylcholine in adrenal glands, following by inhibition of cholinesterase by carbamate insecticides causes release of epinephrine in the 
circulation, which enhances the cellular metabolism proportionally to stimulation of glycogenolysis in the liver, increases consequently glucose levels in the blood of experimental animals treated with pesticides. (Rai et al., 2010; 2011). On the other hand, the accumulation of acetylcholine in some parts of the brain (hypothalamus) results in systemic and prolonged release of humoral factors causing mobilisation of peripheral glycogen stores and thus, blood glucose is additionally increased. The simultaneous increase in catecholamines (epinephrineandnorepinephrine) activates the glycogenolysis, stimulates gluconeo genesis, reduces glucose utilization by tissues, reduce blood insulin levels and increases blood glucose concentrations. (Gupta, 2015). The changes incarbohydrate metabolism (hyperglycaemia) induced by carbamates could be attributed both to their effect on liver enzymes and to the necessity for increased energy supply to the liver for detoxication (Gupta, 2004; Kaur et al., 2012). This reflects at the same time in impaired glycogenolys is and gluconeo genesis, and respectively to higher blood glucose (hyperglycaemia). Additionally, higher blood glucose could result from released endogenous insulin correlating to established morphological changes in the pancreatic tissue. (Rizos, et al., 2004).Simultaneously, glucagon synthesis rate increases, liver glycogen deceases and glycolysis rate becomes enhanced in result from the intoxication stress (Jaiswal et al., 2015).Gupta (1994) assumes that increased blood glucose after carbofuran intoxication could be related to enhanced lipid metabolism in the liver. The author established that 3 hours after the treatment with carbofuran, the liver triglycerides stores were replenished, while blood glucose began to decrease. The relationship between hyperacetylcholinaemia and hyperglycaemia was also confirmed by our results, because as the activity of cholinesterase began to recover, blood glucose levels went down in all treated animals and between post treatment hours 24 and 48,both parameters restored their control levels. These data allowed us recommending hyperglycaemia as a diagnostic marker of carbofuran intoxication.

The toxicological features of the carbamate insecticide carbofuran in dogs treated at increasing doses were completed by blood laboratory tests of renal function. Blood urea levels were increased while those of creatinine varied inconsistently around control values in all experimental dogs. It is acknowledged that urea is the end product of protein and amino acids degradation, produced in the liver via the urea cycle. Increase blood urea concentrations of dogs treated at higher doses of carbofuran was probably due to inhibited protein synthesis and deamination of glucogenic amino acids. On the other hand, increase blood urea could be attributed to the nephrotoxic effect of OCC on renal parenchyma (Jaiswal et al., 2015), correlating to dystrophic and inflammatory morphological changes of the renal parenchyma (Zhelev, 2004), resulting in worsened capacity of kidneys for filtration of urea and creatinine from blood and their elimination with urine. (Kaur et al., 2012). The observed renal disturbances were also associated to functional changes - reduced or interrupted urine excretion (Binev et al., 2014) - an additional reason for increase in blood urea. In our experiments, creatinine in blood was not significantly altered probably because this parameter is changed during kidney damage secondary to acute and chronic intoxications (organophosphate compounds, heavy metals, mycotoxins). The acute intoxication with the carbamate insecticide carbofuran in dogs occurred rapidly and was accompanied with clinical changes within the $1^{\text {st }}$ and the $5^{\text {th }}$ hour (Binev et al., 2014), so in our view, signs of chronicrenal failure were not present and therefore, blood creatinine did not change.

The blood laboratory parameters specific for fat metabolism (cholesterol and triglycerides) in experimental dogs treated with carbofuranat ended to be higher proportionally to the dose of the tested preparation. Hyper cholesterol aemia was present from the $1^{\text {st }}$ hour on ward, and studied amounts were the maximum ones for the entire experimental period. The time course of changes in blood triglycerides was very similar to that of cholesterol concentrations. Triglycerides, however, recovered more rapidly. Our results for increased blood cholesterol and triglycerides agreed with data reported by Zaahkouketal. (2000) and Jaiswaletal. (2015). According to Raietal. (2009) the observed changes could be due to increase in catecholamines, which stimulateli polysis proportionally to observed liver parenchyma changes and obstruction of bile ducts in the liver( Agrawal and Sharma, 2010; Gbadeges in et al., 2014) leading to impaired lipoprotein synthesis and to reduction or interruption of bile secretion in the duodenum, hence to higher blood serum cholesterol and cholestasis. Organo carbamates have a strong affinity to systemic fat depots (Jaiswal et al., 2015) and are capable to stimulate tissue lipogenesis via activation ofacetylCoA (precursor of cholesterol biosynthesis) causing fat dystrophy of visceral organs (Zaahkouk et al., 2000). Our results support the hypothes is that increased blood cholesterol and triglycerides were due to increased catecholamines consequently to then euro toxic effect of carbamate insecticides, rather than to impaired bile excretion. This is further confirmed by the lack of statistically significant changes in total and direct bili rubin concentrations in blood in our study.

The investigations on blood electrolytes in dogs treated at increasing doses of the carbamate insecticide carbofuran demonstrated that the tested toxic compound caused changes in blood magnesium and potassium levels. The other 
electrolytes (chlorides, calcium, inorganic phosphate and sodium) varied around the control values through out the entire study period. Blood magnesium decreased only on post treatment hour 5. No comparable data are reported in the literature, so we suggest that acute hypomagnesaemia was due to the rapid depletion of magnesium ions from the circulation for proper maintenance of the nervous processes, possibly impaired by the strong neurotoxic effect of carbamate pesticides and acetylcholine challenge. Blood potassium levels decreased in all experimental groups by the $1^{\text {st }}$ hour after the intoxication with carbofuran. Hypo kalemia was due at the same time to two events cholinergic cover stimulation and acute pancreatitis development (Rizosetal. 2004). Reduced blood potassium concentrations correlated with electro cardiographic changes (ST segment depression and negativisation with increased $\mathrm{T}$ wave amplitude) established in dogs with experimental acute carbamatein toxication (Binev et al., 2005).

\section{Ethics:-}

I hereby declare all ethical standards have been respected in preparation of the submitted article.

\section{Conflict of Interest:-}

The authors declare that they have no conflict of interest.

\section{Grant Support:-}

This study was funded by project №. №5/2005 and was supported by Faculty of Veterinary Medicine, Stara Zagora, Bulgaria.

\section{References:-}

1. Agrawal, A. and Sharma, B. (2010): Pesticides induced oxidative stressin mammalian systems. Int. J. Biol. Med. Res., 1: 90-104.

2. Aleksic, J., Mercep, D., Aleksic, Z. and Jovanovic, M. (2011): Dog poisoning with furadan 35-ST (carbamate insecticide). Vet. Glasnik, 65: 277-285.

3. Arnot, L.F., Vealec, D.J.H., Steylb, J.C.A. and Myburgh, J.G. (2011): Treatment rationale for dogs poisoned with aldicarb (carbamate pesticide).J. S. Afr. Vet. Assoc., 82: 232-238.

4. Begum, G. and Vijayaraghavan, S. (2001): Carbofuran toxicity on total lipids and free fatty acids in air breathing fish during exposure and cessation of exposure-in vivo.Environ. Monit. Assess, 70: 233-239.

5. Berny, P., Caloni, F., Croubels, S., Sachana, M., Vandenbroucke, V., Davanzo, F. and Guitart, R. (2010): Animal poisoning in Europe. Part 2: Companion animals. Vet. J., 183: 255-259.

6. Binev, R., Russenov,A., Valchev, I. and Nikolov J. (2005): Electrocardiographic studies upon acute intoxication with Carbofuran in dogs. Trak. J. Sci., 3: 59-63.

7. Binev, R., Valchev, I., Russenov, A. and Nikolov, Y. (2014): Clinical toxicological investigations on acute carbofuran intoxication in dogs. Bulg. J. Vet. Med., 17: 61-68.

8. de Siqueira, A., Salvagni, F.A., Yoshida, A.S., Gonçalves-Jr, V., Calefi, A.S., Fukushima, A.R., Spinosa, H.S. and Maiorka, P.C. (2015): Poisoning of cats and dogs by the carbamate pesticides aldicarb and carbofuran. Res. Vet. Sci., 102: 142-149.

9. Gbadegesin, M.A., Owumi, S.E., Akinseye, V. and Odunola, O.A. (2014): Evaluation of hepatotoxicityand clastogenicity of carbofuran in male Wistar rats. Food Chem. Toxicol., 65:115-119.

10. Guitart, R., Croubels, S., Caloni, F., Sachana, M., Davanzo, F., Vandenbroucke, V. and Berny, P. (2010a): Animal poisoning in Europe. Part 1: Farm livestock and poultry. Vet. J., 183: 249-254.

11. Guitart, R., Sachana, M., Caloni, F., Croubels, S., Vandenbroucke, V. and Berny, P. (2010b): Animal poisoning in Europe. Part 3: Wildlife. Vet. J., 183: 260-265.

12. Gupta, R.C. (1994): Carbofuran toxicity. J. Toxicology Environ. Health, 43: 383-418.

13. Gupta, R. (2015): Handbook of toxicology of chemical warfare agents: 2nd edition. Elsivier: 594-597.

14. Jaiswal, S.K., Gupta, V.K., Siddiqi, N.J. and Pandey, R.S. (2015): Hepatoprotective effect of Citrus lemon fruit extract againstcarbofuran induced toxicity in Wistar rats. Chi. J. Biol., ID 686071: 10.

15. Kaur, M. and Sandhir, R. (2006): Comparative effects of acute andchronic carbofuran exposure on oxidative stress and drugmetabolizingenzymes in liver. Drug Chem. Toxicol., 29: 415-421.

16. Kaur, B., Khera, A. and Rajat Sandhir, R. (2012):Attenuation of cellular antioxidant defensemechanisms in kidney of rats intoxicated withcarbofuran. J. Biochem. Mol. Toxicol., 26: 393-398.

17. Kervegant, M., Merigot, L., Glaizal, M., Schmitt, C., Tichadou, L. and de Haro, L. (2013): Paraquat poisonings in France during the European ban: experience of the Poison Control Center in Marseille. J.Med. Toxicol., 9: 144-147. 
18. Novotný, L., Misík, J., Honzlová, A., Ondráček, P., Kuča, K., Vávra, O., Rachač, V. and Chloupek, P. (2011): Incidental poisoning of animals by carbamates in the Czech Republic. J. Appl. Biomed., 9: 157-161.

19. Ogada, D.C. (2014): The power of poison: pesticide poisoning of Africa's wildlife. Ann. N. Y. Acad. Sci., 1322: $1-20$.

20. Rai, D.K. and Sharma, B. (2007): Carbofuran-induced oxidative stressin mammalian brain. Mol. Biotechnol., 37: 66-71.

21. Rai, D.K., Rai, P.K., Gupta, A., Watal, G. and Sharma, B. (2009): Cartap and carbofuran induced alterations in serum lipid profile of Wistar rats. Ind. J. Clinic. Biochem., 24: 198-201.

22. Rai, D.K., Rai, P.K., Watal, G. and Sharma, B. (2010): The Cynodondactylon extract help improve anticholinesterase effects and oxidativestress caused by carbofuran in rat brain. Toxicol. Pathol., 38: E1-E6.

23. Rai, D.K., Sharma,R.K., B. Rai, P.K., Watal, G. and Sharma, B. (2011):Role of aqueous extract of Cynodon dactylon in prevention of carbofuran-induced oxidative stress and acetylcholinesteraseinhibition in rat brain. Cell. Mol. Biol., 57: 135-142.

24. Rizos, E., Liberopoulos, E., Kosta, P., Efremidis, S. and Elisaf, M. (2004): Carbofuran-induced acute pancreatitis. J. Pancreas, 5: 44-47.

25. Ruiz-Suárez, N., Boada, L.D., Henríquez-Hernández, L.A., González-Moreo, F., Suárez-Pérez, A., Camacho,M., Zumbado, M., Almeida-González, M., Travieso-Aja, M. and Luzardo, O.P. (2015): Continued implication of the banned pesticides carbofuran and aldicarb in the poisoning of domestic and wild animals of the Canary Islands (Spain). Sci. Total. Environ.,505: 1093-1099.

26. Soufy, H., Soliman, M., El-Manakhly, E., and Gaafa, A. (2007): Some biochemical and pathological investigations on monosex Tilapia following chronic exposure to carbofuran pesticides. Glob. Vet., 1: 45-52.

27. Thoker, M.A. (2015): Comparative study of biochemical alterations induced by carbofuran andmalathion on Channa punctatus (Bloch.). Int. Res. J. Biol. Sci.,4: 61-65.

28. Vandenbroucke, H., Van Pelt, P. and De Backer, S. (2010): Croubelsanimal poisonings in Belgium: a review of the past decade. Vlaams Diergeneeskd. Tijdschr.,79:Review 259.

29. Vlcek, V. and Pohanka, M. (2012): Carbamate insecticides in the Czech Republic: Health and environmental impacts. Mil. Med. Sci. Lett., 81: 2-8.

30. Zaahkouk, S.A.M., Helal, E.G.E., Abd-Rabo, T.E.I., Somaia, Z.A.R. (2000): Carbamate toxicity and rotective effect of vit. A and vit. E on some biochemical aspects of male albino rats. Egyp. J. Hosp. Med., 1: 60-77.

31. Zhelev, I. (2004): Study on the acute toxicity of carbamate compound carbofuran in fattening pigs. Vet. Med., 8: $43-47$. 